\title{
Difficulties with Use of Cocoa Bean Shell in Food Production and High Voltage Electrical Discharge as a Possible Solution
}

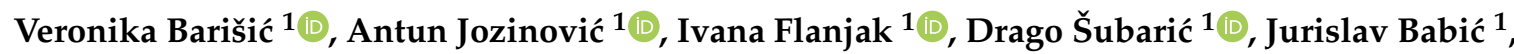

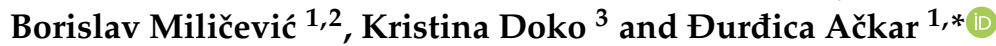 \\ 1 Faculty of Food Technology Osijek, Josip Juraj Strossmayer University of Osijek, Franje Kuhača 20, \\ 31000 Osijek, Croatia; veronika.barisic@ptfos.hr (V.B.); antun.jozinovic@ptfos.hr (A.J.); \\ ivana.flanjak@ptfos.hr (I.F.); drago.subaric@ptfos.hr (D.Š.); jurislav.babic@ptfos.hr (J.B.); \\ borislav.milicevic@ptfos.hr (B.M.) \\ 2 Polytechnic in Požega, Vukovarska 17, 34000 Požega, Croatia \\ 3 Federal Agro Mediterranean Institute, Biskupa Čule 10, 88000 Mostar, Bosnia and Herzegovina; \\ kristina.skender@gmail.com \\ * Correspondence: dackar@ptfos.hr
}

Received: 7 April 2020; Accepted: 9 May 2020; Published: 13 May 2020

\begin{abstract}
The cocoa and chocolate industries have huge problems with the utilization of waste generated during the production process. Waste material generated during production include cocoa pod husk, pulp, and cocoa bean shell. Cocoa shell is a by-product that has great potential because of its composition. It consists of dietary fibers, proteins, polyphenols, methylxanthines, etc. However, despite its favorable composition, cocoa shell often cannot be used directly in food production because it may contain components that are harmful for human health. Cocoa shell can carry mycotoxins, different microorganisms, polycyclic aromatic hydrocarbons, and heavy metals. High voltage electrical discharge presents a novel non-thermal method that has great potential for the decontamination of waste materials and can also be used for extraction of valuable compounds from cocoa shell.
\end{abstract}

Keywords: cocoa shell; HVED; waste material; sustainable production

\section{Introduction}

The cocoa industry faces fluctuation of cocoa bean price and social and political instabilities in producing countries. The environmental aspects of the cocoa industry present some relevant issues, and one of them is management of waste material generated during production [1,2].

The market for functional food is constantly expanding, so it is not surprising that agro-industrial wastes are seen as new ingredients for this type of products [3]. Economic, social, and environmental sustainability is the goal of every food production, including that of the chocolate industry. Many institutions want to ensure waste management to achieve this goal [4].

Cocoa shell is a by-product of the cocoa industry that has a high nutritional value. It can be used in the food industry, as well as in pharmaceutical, cosmetic, and agricultural industries. A more detailed review of its use in different industries is given in the paper by Panak Balentić et al. [5].

The production of cocoa beans can be divided into three stages:

- Growing, harvesting, and pre-processing;

- Primary cocoa processing and production of semi-finished products; and

- Chocolate industry-manufacturing of finished products [6]. 
High voltage electrical discharge (HVED) has become very interesting to many scientists because it can degrade organic compounds and inactivate bacteria, viruses, and yeasts [7]. This treatment leads to a number of chemical and physical processes: production of ultraviolet light, shock waves, production of reactive species, etc. [8]. All these changes are responsible for HVED's capability to be a disinfection and extraction technology.

This review shows the benefits and shortcomings of using cocoa shell in food production. A possible solution for problems that occur with the use of cocoa shell in food production is stated.

\section{Cocoa Shell}

The cocoa industry generates large amounts of waste that consist of pod husk, pulp, and bean shell. Namely, cocoa beans, which are the main ingredient in chocolate production, are removed from the cocoa pod, after which they are fermented and dried. Cocoa bean shell is removed from seeds before or after roasting of the beans [9].

After the separation of the shell from the seed, it is usually discarded or sold as agricultural mulch. Since the shell presents $12 \%-20 \%$ of the bean, it is obvious that this is the largest waste generated after processing the beans [9-11]. According to International Cocoa Organization [12], the world generation of cocoa waste can be estimated to 700 thousand tons per year.

Cocoa shell has an interesting composition. It is rich in dietary fibers, proteins [13], polyphenols [14,15], methylxanthines [16], etc.

Dietary fibers are generally divided into soluble and insoluble fibers. The soluble/insoluble ratio is very important in human nutrition, and cocoa bean shell has a ratio close to desirable, giving it potential for direct implementation in food [17]. Dietary fibers of cocoa shell are mainly composed of pectin and cellulose [13]. In addition, cocoa shell is rich in flavanols (catechin and epicatechin), which have an antioxidant activity, and methylxanthines (theobromine and caffeine), which have an effect on the human nervous system [18,19]. Okiyama et al. [20] investigated the lipid profile of cocoa shell and concluded that it is similar to that of cocoa butter, which could lead to its application as a partial substitute for cocoa butter.

\subsection{Use of Cocoa Shell in Food Production}

Cocoa shell composition has driven many scientists into implementing cocoa shell directly in food products and investigating the properties and sensorial acceptance of the obtained products. In addition, there are research that investigated the application of different components of cocoa shell as a food ingredient. This subsection gives an overview of papers that have addressed this topic.

Martinez-Cervera et al. [21] used soluble dietary fiber extracted from cocoa shell in the production of chocolate muffins. Fibers were used as fat replacers and the results showed decreased hardening during storage, good texture, higher moisture, and pleasant color of enriched muffins. Soluble dietary fibers from cocoa shell were also used in production of wheat bread, showing a softening effect [22]. It was concluded that these fibers can be used up to $6 \%$ and do not have a negative effect on sensory acceptability and storage of bread. Enrichment of products like muffins and bread, which are consumed often, with dietary fibers from the cocoa shell can have beneficial effects on glucose absorption, as was shown in an in vitro study by Nsor-Atindana et al. [23].

Mazzutti et al. [19] used cocoa shell to obtain lipid-enriched extract and phenolic-rich extract. These products showed great potential for incorporation in food products. Another study conducted with extracts of cocoa shell aimed to protect polyphenols that are present in this kind of extract. Papillo et al. [24] used spray-drying with maltodextrins to achieve this. Results showed that polyphenols in these extracts were protected during baking and storage.

Alkalized cocoa shell has also found its way into food production. Bernaert and Rysscher [25] used it for production of a cocoa beverage with a unique taste and rich in dietary fibers. In another study, they concluded that cocoa shell powder could be used in different food products as a replacement for cocoa powder [26]. Alkalized cocoa shell was used also in the production of cookies, and the obtained 
product showed higher resistance to breaking compared to wheat cookies [27]. Another study was conducted to investigate functional beverages with cocoa shell [28], where beverages with the highest content of bioactive compounds were the least appreciated by consumers. This was probably because of polyphenols and methylxanthines that give an astringent taste to these products.

Some direct implementations of cocoa shell in food products without previous processing include the production of pork sausages [29] and extruded snack products [30]. Pork sausages with levels of cocoa shell of $1 \%$ or lower had improved color, viscosity, moisture content, and emulsion stability. An interesting discovery was also that the addition of cocoa bean shell could inhibit lipid oxidation in these kinds of products. Jozinović et al. [30] added cocoa shell in extruded snack products in amounts of $5 \%, 10 \%$, and $15 \%$. This enrichment increased resistant starch and polyphenol content. Although physical properties were slightly poorer than in conventional products, they were still acceptable.

Cocoa shell will also be interesting for incorporation in chocolates because it would not need to be transported from chocolate factories. It would be directly used in chocolate production, which would decrease the cost of its use. A great deal of research has been done with focus on enrichment of chocolates with fiber sources where they replaced sugar or fat [31]. This gives promising hope that the use of cocoa shell in chocolate production could come to life.

\subsection{Problems with Use of Cocoa Shell in Food Production}

Since it is obvious that cocoa bean shell has great potential and it is rich in many bioactive components that can benefit human health, why is it not used in food production yet? One of the reasons is that cocoa shell may contain undesirable components that need to be removed before its incorporation in food products. Some of these components are mycotoxins, heavy metals, polycyclic aromatic hydrocarbons (PAHs), and microorganisms.

\subsubsection{Mycotoxins}

Cocoa beans are fermented, dried, and stored most commonly in unhygienic conditions. That is obvious from the fact that they are often contaminated with Aspergillus, Eurotium, and Absidia species [10]. Copetti et al. [32] reported that ochratoxin A, which is produced by fungi of Aspergillus and Penicillium genera, are concentrated in cocoa shell. This toxin is present in a wide variety of foods like coffee beans, dried fruit, and cereals [33]. Only a small part of this toxin is present in cocoa nibs. Aflatoxins B1, B2, G1, and G2 have been found in cocoa shell. It was concluded that they appeared more frequently in cocoa shell than other parts of bean, and that they appeared in $11 \%$ of the samples [34]. These components are very stable and cannot be completely destroyed during processes conducted during the production of chocolate [35].

\subsubsection{Heavy Metals}

Cocoa bean may be contaminated with heavy metals because of environmental and external influences [36]. A major concern is the presence of nickel (Ni), cadmium (Cd), chromium (Cr), and lead $(\mathrm{Pb})$ [37]. Most research mentioned below were conducted to examine heavy metal contents in chocolate and cocoa products [38,39]. Increased contamination was mostly because of the use of fertilizers, pesticides, insecticides, etc. If these activities are not controlled and managed according to Good Agricultural Practice (GAP) and Good Manufacturing Practice (GMP), they can lead to increased content of heavy metals [40]. Additionally, fermentation, drying, crushing, and contact with metal devices during processing can affect the content of heavy metals [41].

Cocoa shell in most cases has higher content of these compounds because of its high absorption capacity. This characteristic is used in a few researches to examine cocoa shell as a new adsorbent for the removal of heavy metals from polluted water [42,43]. 


\subsubsection{Polycyclic Aromatic Hydrocarbons (PAHs)}

PAHs are known as genotoxic carcinogens and in cocoa beans can be produced during drying and roasting $[44,45]$. They are formed in roasted foods rich in carbohydrates through two processes: pyrolysis and pyrosynthesis $[46,47]$. The increased content of PAHs in cocoa beans is most often the result of inappropriate drying. The highest risk of contamination is present in artificial drying when producers use firewood or fossil fuel [48]. In addition, Ciecierska [45] concluded that even low temperatures during roasting of beans favor the development of PAHs. Since, most often, cocoa beans are roasted with cocoa shell, there is a high possibility that the cocoa shell is also contaminated with PAHs. Agus et al. [49] reported that roasted cocoa shell had lower amounts of PAHs than dried cocoa shell. This could be due to migration of these compounds in cocoa nibs during roasting.

\subsubsection{Microorganisms}

During drying in cocoa farms, birds and insects frequently come into contact with cocoa seeds. They are transmitters of Escherichia coli and Salmonella [6]. Although cocoa beans are subjected to roasting, the research of Izurieta and Komitopoulou [50] showed that Salmonella strains present on cocoa shell were heat resistant. To minimize risk of contamination of cocoa beans, good hygiene and manufacturing practices should be implemented in cocoa farms. Leaving cocoa beans unprotected should be avoided so that contact with transmitters of contamination can be reduced [51].

\section{High Voltage Electrical Discharge (HVED)}

High voltage electrical discharge treatment is a low-energy and non-thermal technology that has great potential for use in the utilization of by-products in the food industry.

\subsection{Work Principle of HVED Device}

HVED technology is based on generation of electric discharges directly in water. This contact generates physio-chemical changes and chemical processes in water [52]. Applying high voltage and intensity pulses of short duration between two electrodes submerged in liquid leads to ionization. During this process, three phases occur: electric pulse generation, current discharge, and electric arc formation [53]. The process is accelerated with bubbles present in the solution or generated during localized heating. Electron avalanche from high-voltage- to ground electrode will occur if the potential difference between electrodes is sufficient. During this process, due to large amounts of energy used, a number of oxidizing species is generated [4].

HVED systems can be divided into batch, continuous, and circulating systems. The basic mechanism of these three systems is the same, but local electric field concentration modes are different [54].

For use of HVED technology in extraction or any other treatment, there are two important parameters: total HVED treatment duration $\left(t_{\text {HVED }}\right)$ (Equation (1)) and HVED energy input ( $w_{\text {HVED }}$ ) (Equation (2)) [54]:

$$
t_{H V E D}(s)=n \times t_{i}
$$

where $n$ is number of discharges and $t_{i}$ is discharge duration (s).

$$
w_{H V E D}\left(\frac{k J}{k g}\right)=\frac{E_{p} \times n}{m}
$$

where $E_{p}$ is energy of one pulse $(k J), n$ is number of discharges, and $m$ is mass of suspension $(k g)$.

During HVED treatment, photonic dissociation of water occurs, which leads to emission of UV-light and $\mathrm{OH}$ radicals. The UV-light can inactivate cells by damaging DNA and the created shock waves can fragmentize tissue of products that are treated. The electric strength of the field is directly proportional to the poration of the cell membrane, and this phenomenon is called electroporation $[54,55]$. 


\subsection{Description of HVED Device}

Since there are many custom-made devices that are used in research and some of them are well described by Takaki et al. [56], only the high voltage electrical discharge device (Figure 1) that was custom made for Faculty of Food Technology Osijek by Ingeniare CPTS1 is described in this subsection as an example. The pulse generator of high voltage contains a $30 \mathrm{kV}$ impulse generator with a variable pulse frequency of $20 \mathrm{~Hz}$ to $100 \mathrm{~Hz}$. The impulse generator can be replaced so that the voltage can be adjusted according to the needs of the experiment. The generator scheme (Figure 2) shows that it consists of a high-voltage DC generator, an energy tank (capacitor), a high-voltage switch, a chamber, and an automatic control unit. The automatic control unit provides capability to control time of treatment, pulse frequency, and mixing speed.

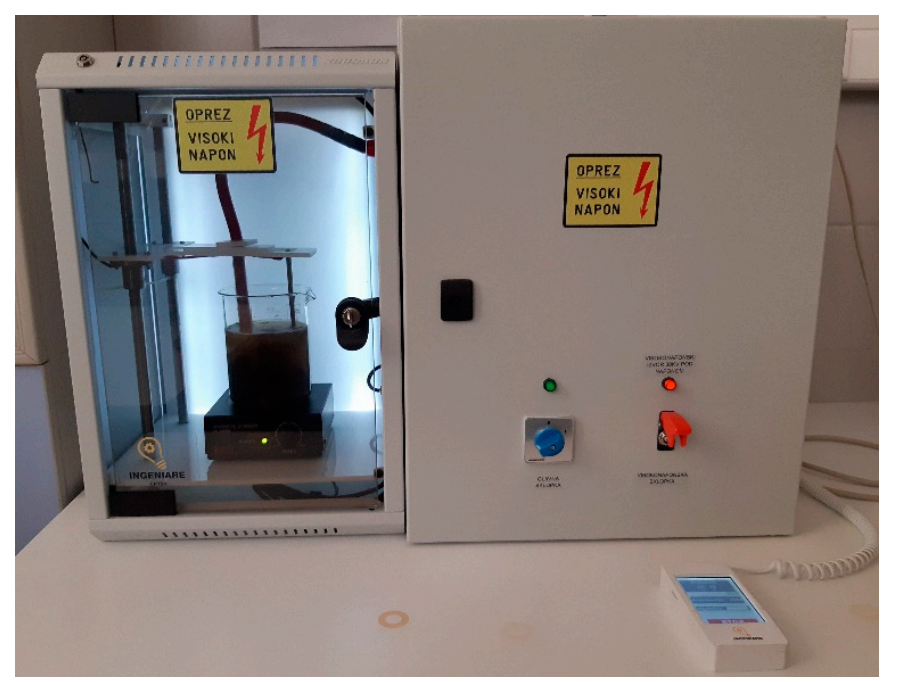

Figure 1. High voltage electrical discharge device.

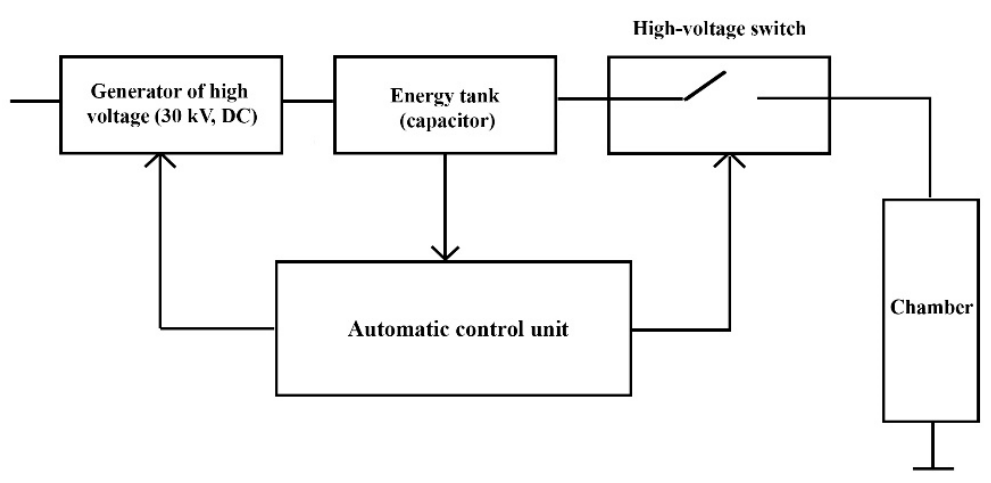

Figure 2. Scheme of generator.

High voltage electrodes are located in the treatment chamber and are attached to the electrode carrier with the ability to adjust the distance between the electrodes. The high voltage INOX electrode and the plate or ground electrode $(45 \mathrm{~mm})$ are immersed in the solution during the treatment. The height of the electrodes can also be adjusted. The distance between the electrodes is adjusted according to the conductivity of the sample that will be treated, which depends on both the type of sample and the concentration of the solution. The conductivity of the solution must be measured before the treatment. The effect of water conductivity on formation of shock waves was studied by Cathignol et al. [57].

\subsection{HVED Application}

HVED is mostly used for the extraction of polyphenols, proteins, and pectin from waste materials $[4,58,59]$. In this paper, we want to show other perspectives of this technology that 
will open the possibility of using HVED as a decontamination and extraction technology at the same time.

HVED can be used for inactivation of bacteria like Sallmonella spp., Eschericia coli, Listeria, etc. [60]. Zhao et al. [61] designed an atmospheric air dielectric barrier discharge device, which they used to uniformly decontaminate fruit surface. They reported satisfactory results for the removal of S. aureus without damaging the fruit surface. In addition, there are many examples of effective use of cold plasma in the removal of mycotoxins and fungi, even damaging spores [62]. These imply that HVED could also have such an effect in liquid media. Anpilov et al. [63] reported that HVED was effective in the destruction of Escherichia coli in water, probably because of the generation of different radicals and UV radiation. Reactive oxygen species and hydrogen peroxide produced during treatment induce oxidative stress that has a major effect on microbial inactivation. These products oxidize membrane components of microorganisms [64]. Some researchers concluded that the efficiency of HVED is due to the combination of physical, chemical, and electrical effects, and not just one factor [65]. During treatment, the formation of hydrogen peroxide occurs, which further leads to the formation of $\mathrm{H}_{3} \mathrm{O}^{+}$, which is mostly responsible for a decrease of $\mathrm{pH}$. Bacteria such as Escherichia coli is especially sensitive to low $\mathrm{pH}$, which leads to its disruption [66]. However, $\mathrm{pH}$ alone could not be responsible for the inactivation of these proportions [8]. The combination of UV light and $\mathrm{H}_{2} \mathrm{O}_{2}$ can lead to the mutation and damage of DNA. Ozone is an additional factor that contributes to disinfection possibilities of HVED, since it is a known disinfectant [67].

HVED treatment of cocoa shell conducted on the device described in this paper showed that this is a good procedure for the removal of 5-hydroxymethylfurfural and acrylamide [68]. It is well established that acrylamide is carcinogenic and is even regulated in the EU for different types of food products. Tessier et al. [69] reported decontamination of PAHs with corona discharge. This process was conducted in solid phase so it is not certain in which way these compounds will behave in water during discharge. Further research is needed to see if this process may successfully remove PAHs from cocoa bean shell. It is known that this technology can also be used for the removal of different organic impurities from water, possibly due to the same reasons [4]. The potential of HVED for decontamination of materials and liquids lies in the fact that species $\left(\mathrm{O}, \mathrm{OH}, \mathrm{O}_{3}\right)$ that are generated during discharges in liquid are very active. The radicals that are created by dissociation of water can oxidize organic compounds that are present in material or liquid that is treated, and can therefore remove them $[70,71]$. During electrical treatment, advanced oxidation processes are known to degrade a range of organic compounds [72]. Hydroxyl radical, ozone, and hydrogen peroxide are species that directly attack organic compounds [73]. Du et al. [74] also managed to reduce $74.4 \%$ of PAHs during arc discharge. They proposed that $\mathrm{OH}$ probably reacted with the aromatic ring, where further reaction with oxygen resulted in ring-cleavage products.

Plasma discharges are known for their possibility of removing fungi and mycotoxins [62]. Ouf et al. [75] eliminated ochratoxin A with cold plasma after 7.5 min. Plasma-induced reactive species are mainly responsible for decontamination, but UV light also plays an important role. Park et al. [76] managed to completely degrade aflatoxins, ochratoxins, and deoxynivalenol with cold plasma treatment. However, mycotoxins in food matrix could be a little more difficult to degrade because the matrix could slow down the effect of plasma and react with part of the reactive species [77]. It was reported that this treatment destroys the integrity of cellular structure of Aspergillus spores [78].

Discharge treatment proved to be effective in decreasing the content of $\mathrm{Pb}, \mathrm{Cd}, \mathrm{Fe}$, and $\mathrm{Mn}$ in waste water, probably due to formation of insoluble oxides and hydroxides [79]. Rincon and Motta [80] also managed to remove zinc, copper, and nickel from waste water with an electro coagulation method. This implies that the process could be effective in the removal of metals from cocoa shell.

Since HVED technology is mostly used for extraction, this can be an additional reason for using this method. It would be economically viable to use the extract obtained after cocoa shell treatment to produce bioactive components, proteins, or pectin. Jokić et al. [81] used this method for the extraction of polyphenols and methylxanthines. In contrast to this study, where the cocoa shell was milled, 
Barišić et al. [15] came to the conclusion that unmilled cocoa shell treated with HVED had a higher proportion of polyphenols and methylxanthines than control samples mixed in water. Additionally, HVED extraction of proteins from Camellia olcifera seed cake [82] and pectin from sugar beet pulp [83] was conducted.

When compared to other conventional extraction techniques, HVED was shown as a great process to obtain higher phenolic content in extracts from olive leaves [84] and grape seeds [85]. In the case of grape seeds, HVED also affected the size of grape seeds because of the generated shocks that can disrupt tissue and cellular structures [86]. At the same time, it was less selective regarding the amount of anthocyanins recovered during the extraction.

Due to its great potential for extraction of various biocomponents, shorter treatment, and less thermal destructiveness compared to other techniques, HVED has already proven to be an excellent extraction technique. If we also take into consideration the potential for decontamination of water and different biomaterials, this technology could replace several technologies currently present in the industry, not only for treatment of cocoa shell, but for other waste materials as well.

\section{Conclusions}

The cocoa industry has a large problem with the disposal of waste generated during production. One of the most interesting waste materials is cocoa bean shell. It is rich in dietary fibers, bioactive compounds, proteins, etc.-compounds that can benefit human health. However, cocoa shell may contain some undesirable compounds that need to be removed before incorporation into food products. High voltage electrical discharge treatment was shown as a promising non-thermal technology for the utilization of food by-products, which can solve the problem of harmful compounds present in cocoa shell. Different types of HVED treatment, including plasma, have been shown to be efficient in the decontamination of various food products, including the destruction of microorganisms both pathogenic and spoilage, and removal of heavy metals, PAHs, HMF, and acrylamide. Future research should focus on revealing actual mechanisms of HVED on specific compounds and microorganisms, and on the exploration of optimal conditions of treatment regarding the desired effect, but negative effects (such as potential release of metals from electrodes) should not be disregarded.

Author Contributions: All authors contributed to the conceptualization and implementation of the research study; writing—original draft preparation, V.B., A.J., I.F., and Đ.A.; writing—review and editing, B.M., D.Š., J.B., and K.D. All authors have read and agreed to the published version of the manuscript.

Funding: This work has been supported in part by Croatian Science Foundation under the project "Application of cocoa husk in production of chocolate and chocolate-like products" (UIP 2017-05-8709).

Conflicts of Interest: The authors declare no conflict of interest.

\section{References}

1. The International Cocoa Organization. The World Cocoa Economy: Past and Present; ICCO: London, UK, 2012.

2. Ntiamoah, A.; Afrane, G. Environmental impacts of cocoa production and processing in Ghana: Life cycle assessment approach. J. Clean. Prod. 2008, 16, 1735-1740. [CrossRef]

3. Gullón, P.; Gonzáles-Muñoz, M.J.; Parajó, J.C. Manufacture and prebiotic potential of oligosaccharides derived from industrial solid wastes. Bioresour. Technol. 2011, 102, 6112-6119. [CrossRef]

4. Puértolas, E.; Barba, F.J. Electrotechnologies applied to valorization of by-products from food industry: Main findings, energy and economic cost of their industrialization. Food Bioprod. Process. 2016, 100, $172-184$. [CrossRef]

5. Panak Balentić, J.; Ačkar, Đ.; Jokić, S.; Jozinović, A.; Babić, J.; Miličević, B.; Šubarić, D.; Pavlović, N. Cocoa Shell: A By-Product with Great Potential for Wide Application. Molecules 2018, 23, 1404. [CrossRef]

6. Da Silva do Nascimento, M.; da Silva, N.; da Silva, I.F.; da Silva, J.d.C.; Marques, É.R.; Barbosa Santos, A.R. Eteropathogens in cocoa pre-processing. Food Control 2010, 21, 408-411. [CrossRef]

7. Grymonpré, D.R.; Sharma, A.K.; Finney, W.C.; Locke, B.R. The role of Fenton's reaction in aqueous phase pulsed streamer corona reactors. Chem. Eng. J. 2001, 82, 189-207. [CrossRef] 
8. Chen, C.-W.; Lee, H.-M.; Chang, M.-B. Influence of $\mathrm{pH}$ on inactivation of aquatic microorganism with a gas-liquid pulsed electrical discharge. J. Electrostat. 2009, 67, 703-708. [CrossRef]

9. Vásquez, Z.S.; de Carvalho Neto, D.P.; Pereira, G.V.M.; Vandenberghe, L.P.S.; de Oliveira, P.Z.; Tiburcio, P.B.; Rogez, H.L.G.; Góes Neto, A.; Soccol, C.R. Biotechnological approaches for cocoa waste management; A review. Waste Manag. 2019, 90, 72-83. [CrossRef]

10. Okiyama, D.C.G.; Navarro, S.L.B.; Rodrigues, C.E.C. Cocoa shell and its compounds: Applications in the food industry. Trends Food Sci. Technol. 2017, 63, 103-112. [CrossRef]

11. Djali, M.; Siti Setiasih, I.; Rindiantika, T.S. Chemical characteristics, phytochemical and cacao shell toxicity changes during the processing of cocoa beans. Asian J. Agri. Biol. 2018, 6, 103-114.

12. International Cocoa Organization. Production of Cocoa Beans; ICCO Quarterly Bulletin of Cocoa Statistics, XLII; ICCO: London, UK, 2016.

13. Redgwell, R.; Trovato, V.; Merinat, S.; Curti, D.; Hediger, S.; Manez, A. Dietary fibre in cocoa shell: Characterization of component polysaccharides. Food Chem. 2003, 81, 103-112. [CrossRef]

14. Martínez, R.; Torres, P.; Meneses, M.A.; Figueroa, J.G.; Pérez-Álvarez, J.A.; Viuda-Martos, M. Chemical, technological and in vitro antioxidant properties of cocoa (Theobroma cacao L.) co-products. Food Res. Int. 2012, 49, 39-45. [CrossRef]

15. Barišić, V.; Flanjak, I.; Križić, I.; Jozinović, A.; Šubarić, D.; Babić, J.; Miličević, B.; Ačkar, Đ. Impact of high-voltage electric discharge treatment on cocoa shell phenolic components and methylxanthines. J. Food Process Eng. 2020, 43, e13057. [CrossRef]

16. Rusconi, M.; Conti, A. Theobroma cacao L., the food of the Gods: A scientific approach beyond myths and claims. Pharmacol. Res. 2010, 61, 5-13. [CrossRef]

17. Vojvodić, A.; Komes, D.; Vovk, I.; Belščak-Cvitanović, A.; Bušić, A. Compositional evaluation of selected agro-industrial wastes as valuable sources for the recovery of complex carbohydrates. Food Res. Int. 2016, 89, 565-573. [CrossRef]

18. Grillo, G.; Boffa, L.; Binello, A.; Mantegna, S.; Cravotto, G.; Chemat, F.; Dizhbite, T.; Lauberte, L.; Telysheva, G. Cocoa bean shell waste valorization; extraction from lab to pilot-scale cavitation reactors. Food Res. Int. 2019, 115, 200-208. [CrossRef]

19. Mazzutti, S.; Rodrigues, L.G.G.; Mezzomo, N.; Venturi, V.; Ferreira, S.R.S. Integrated green-based processes using supercritical $\mathrm{CO}_{2}$ and pressurized ethanol applied to recover antioxidant compouds from cocoa (Theobroma cacao) bean hulls. J. Supercrit. Fluid 2018, 135, 52-59. [CrossRef]

20. Okiyama, D.C.G.; Soares, I.D.; Toda, T.A.; Oliveira, A.L.; Rodrigues, C.E.C. Effect of the temperature on the kinetics of cocoa bean shell fat extraction using pressurized ethanol and evaluation of the lipid fraction and defatted meal. Ind. Crops. Prod. 2019, 130, 96-103. [CrossRef]

21. Martínez-Cervera, S.; Salvador, A.; Muguerza, B.; Moulay, L.; Fiszman, S.M. Cocoa fibre and its application as a fat replacer in chocolate muffins. LWT 2011, 44, 729-736. [CrossRef]

22. Collar, C.; Rosell, C.M.; Muguerza, B.; Moulay, L. Breadmaking performance and keeping behavior of cocoa-soluble fiber-enriched wheat breads. Food Sci. Technol. Int. 2009, 15, 79-87. [CrossRef]

23. Nsor-Atindana, J.; Zhong, F.; Mothibe, K.J. In vitro hypoglycemic and cholesterol lowering effects of dietary fiber prepared from cocoa (Theobroma cacao L.) shells. Food Funct. 2012, 3, 1044. [CrossRef]

24. Papillo, V.A.; Locatelli, M.; Travaglia, F.; Bordiga, M.; Garino, C.; Coïsson, J.D.; Arlorio, M. Cocoa hulls polyphenols stabilized by microencapsulation as functional ingredient for bakery applications. Food Res. Int. 2019, 115, 511-518. [CrossRef]

25. Bernaert, H.; Ruysscher, I.D. Process, Use, and Product. U.S. Patent 2016135478A1, 27 January 2016.

26. Bernaert, H.; Ruysscher, I.D. Process of Producing Cocoa Shell Powder. U.S. Patent 9,375,024B2, 26 June 2013.

27. Handojo, L.; Triharyogi, H.; Indarto, A. Cocoa bean shell waste as potential raw material for dietary fiber powder. Int. J. Recycl. Org. Waste Agric. 2019, 8, 485-491. [CrossRef]

28. Rojo-Poveda, O.; Barbosa-Pereira, L.; Mateus-Reguengo, L.; Bertolino, M.; Stévigny, C.; Zeppa, G. Effects of Particle Size and Extraction Methods on Cocoa Bean Shell Functional Beverage. Nutrients 2019, 11, 867. [CrossRef]

29. Choi, J.; Kim, N.; Choi, H.Y.; Han, Y.S. Effect of Cacao Bean Husk Powder on the Quality Properties of Pork Sausages. Food Sci. Anim. Resour. 2019, 39, 742-755. [CrossRef] 
30. Jozinović, A.; Panak Balentić, J.; Ačkar, Đ.; Babić, J.; Pajin, B.; Miličević, B.; Guberac, S.; Vrdoljak, A.; Šubarić, D. Cocoa husk application in the enrichment of extruded snack products. J. Food Process Preserv. 2019, 43, e13866. [CrossRef]

31. Barišić, V.; Jozinović, A.; Flanjak, I.; Šubarić, D.; Babić, J.; Miličević, B.; Jokić, S.; Ačkar, Đ. Effect of addition of fibers and polyphenols on properties of chocolate-A review. Food Rev. Int. 2019. [CrossRef]

32. Copetti, M.V.; Iamanaka, B.T.; Nester, M.A.; Efraim, P.; Taniwaki, M.H. Occurrence of ochratoxin A in cocoa by-products and determination of its reduction during chocolate manufacture. Food Chem. 2013, 136, 100-104. [CrossRef]

33. Brera, C.; Debegnach, F.; De Santis, B.; Iafrate, E.; Pannunzi, E.; Berdini, C.; Prantera, E.; Gregori, E.; Miraglia, M. Ochratoxin A in cocoa and chocolate products from the Italian market: Occurrence and exposure assessment. Food Cont. 2011, 22, 1663-1667. [CrossRef]

34. Copetti, M.V.; Iamanaka, B.T.; Pereira, J.L.; Lemes, D.P.; Nakano, F.; Taniwaki, M.H. Determination of aflatoxins in by-products of industrial processing of cocoa beans. Food Addit. Contam. Part A 2012, 29, 972-978. [CrossRef]

35. Bonvehi, J.S. Occurrence of ochratoxin A in cocoa products and chocolate. J. Agric. Food Chem. 2004, 52, 6347-6352. [CrossRef]

36. Amézqueta, S.; Gonzalez-Penas, E.; Murillo, M.; de Cerain, A.L. Occurrence of ochratoxin A in cocoa beans: Effect of shelling. Food Addit. Contam. 2005, 22, 590-596. [CrossRef]

37. Assa, A.; Noor, A.; Yunus, M.R.; Djide, M.N. Heavy metal concentrations in cocoa beans (Theobroma cacao L.) originating from East Luwu, South Sulawesi, Indonesia. J. Phys. Conf. Ser. 2018, 979, 12011. [CrossRef]

38. Rankin, C.W.; Nriagu, J.O.; Aggarwal, J.K.; Arowolo, T.A.; Adebayo, K.; Flegal, A.R. Lead contamination in cocoa and cocoa products: Isotopic evidence of global contamination. Environ. Health Perspect. 2005, 113, 1344-1348. [CrossRef]

39. Dahiya, S.; Karpe, R.; Hegde, A.; Sharma, R.M. Lead, cadmium, and nickel in chocolates and candies from suburban areas of Mumbai India. J. Food Compost. Anal. 2005, 18, 517-522. [CrossRef]

40. Aikpopodion, P.E.; Odule, A.; Osobamiro, O.C.; Oduwole, T.; Ademola, S.M. A survey of copper, lead, cadmium and zinc residues in cocoa beans obtained from selected plantations in Nigeria. J. Chem. Pharm. Res. 2013, 56, 88-98.

41. Kruszewski, B.; Obiedziński, M.W.; Kowalskad, J. Nickel, cadmium and lead levels in raw cocoa and processed chocolate mass materials from three different manufacturers. J. Food Compos. Anal. 2018, 66, 127-135. [CrossRef]

42. Meunier, N.; Laroulandie, J.; Blais, J.F.; Tyagi, R.D. Lead Removal from Acidic Solutions by Sorption on Cocoa Shells: Effect of Some Parameters. J. Environ. Eng. 2003, 129, 693-698. [CrossRef]

43. Meunier, N.; Blais, J.F.; Tyagi, R.D. Removal of heavy metals from acid soil leachate using cocoa shells in a batch counter-current sorption process. Hydrometallurgy 2004, 73, 225-235. [CrossRef]

44. Scientific Committee on Food. Polycyclic Aromatic Hydrocarbons-Occurrence in Foods, Dietary Exposure and Health Effects. Report No. SCF/CS/CNTM/PAH/29 Add1 Final. 4 December 2002. Available online: http://ec.europa.eu.int/comm/food/fs/sc/scf/index_en.html (accessed on 27 February 2020).

45. Ciecierska, M. Cocoa beans of different origins and varieties and their derived products contamination with polycyclic aromatic hydrocarbons. Food Chem. 2020, 317, 126408. [CrossRef]

46. Cheng, W.; Liu, G.; Wang, X.; Liu, X.; Liu, B. Formation of benzo[a]pyrene in sesame seeds during the roasting process for production of sesame seed oil. J. Am. Oil Chem. Soc. 2015, 92, 1725-1733. [CrossRef]

47. Singh, S.G. Polycyclic Aromatic Hydrocarbons formed during Roasting Process in Arabica Coffee Beans; Thapar University: Punjab, India, 2013.

48. Misnawi, J. Effect of cocoa bean drying methods on polycyclic aromatic hydrocarbons contamination in cocoa butter. Int. Food Res. J. 2012, 19, 1589-1594.

49. Agus, B.A.P.; Hussain, N.; Selamat, J. Quantification of PAH4 in Roasted Cocoa Beans Using QuEChERS and Dispersive Liquid-Liquid Micro-extraction (DLLME) Coupled with HPLC-FLD. Food Chem. 2019, 125398. [CrossRef] [PubMed]

50. Izurieta, W.P.; Komitopoulou, E. Effect of moisture on salmonella spp. heat resistance in cocoa and hazelnut shells. Food Res. Int. 2012, 45, 1087-1092. [CrossRef] 
51. do Nascimento, M.D.S.; Pena, P.O.; Brum, D.M.; Imazaki, F.T.; Tucci, M.L.S.; Efraim, P. Behavior of Salmonella during fermentation, drying and storage of cocoa beans. Int. J. Food Microbiol. 2013, 167, 363-368. [CrossRef]

52. Barba, F.J.; Puértolas, E.; Brncic, M.; Panchev, I.N.; Dimitrov, D.A.; Athes-Dutour, V.; Mousaa, M.; Souchon, I. Food Waste Recovery Processing Technologies and Industrial Techniques; Galanakis, C.M., Ed.; Elsevier: Cambridge, MA, USA, 2015; pp. 249-272.

53. Boussetta, N.; Vorobiev, E. Extraction of valuable biocompounds assisted by high voltage electrical discharges: A review. Comptes Rendus Chim. 2014, 17, 197-203. [CrossRef]

54. Li, Z.; Fan, Y.; Xi, J. Recent advances in high voltage electric discharge extraction of bioactive ingredients from plant materials. Food Chem. 2019, 277, 246-260. [CrossRef]

55. El Kantar, S.; Boussetta, N.; Rajha, H.N.; Maroun, R.G.; Louka, N.; Vorobiev, E. High voltage electrical discharges combined with enzymatic hydrolysis for extraction of polyphenols and fermentable sugars from orange peels. Food Res. Int. 2018, 107, 755-762. [CrossRef]

56. Takaki, K.; Hayashi, N.; Wang, D.; Ohshima, T. High-voltage technologies for agriculture and food processing. J. Phys. D Appl. Phys. 2019, 52. [CrossRef]

57. Cathignol, D.; Mestas, J.L.; Gomez, F.; Lenz, P. Influence of water conductivity on the efficiency and the reproducibility of electrohydraulic shock wave generation. Ultrasound Med. Biol. 1991, 17, 819-828. [CrossRef]

58. Boussetta, N.; Lebovka, N.; Vorobiev, E.; Adenier, H.; Bedel-Cloutour, C.; Lanoisellé, J.L. Electrically assisted extraction of soluble matter from chardonnay grape skins for polyphenol recovery. J. Agric. Food Chem. 2009, 57, 1491-1497. [CrossRef] [PubMed]

59. Barba, F.J.; Grimi, N.; Vorobiev, E. Evaluating the potential of cell disruption technologies for green selective extraction of antioxidant compounds from Stevia rebaudiana Bertoni leaves. J. Food Eng. 2015, 149, $222-228$. [CrossRef]

60. Niemira, B.A. Cold Plasma Decontamination of Foods. Annu. Rev. Food. Sci. Technol. 2012, 3, $125-142$. [CrossRef] [PubMed]

61. Zhao, Y.; Xia, Y.; Xi, T.; Zhu, D.; Zhang, Q.; Qi, Z.; Liu, D.; Wang, W. Control of pathogenic bacteria on the surface of rolling fruits by an atmospheric pressure air dielectric barrier discharge system. J. Phys. D Appl. Phys. 2020, 53. [CrossRef]

62. Gavahian, M.; Cullen, P.J. Cold Plasma as an Emerging Technique for Mycotoxin-Free Food: Efficacy, Mechanisms, and Trends. Food Rev. Int. 2020, 36, 1-22. [CrossRef]

63. Anpilov, A.M.; Barkhudarov, E.M.; Christofi, N.; Kopev, V.A.; Kossyi, I.A.; Taktakishvili, M.I.; Zadiraka, Y. 2002-Pulsed high voltage electric discharge disinfection of microbially contaminated liquids. Lett. Appl. Microbiol. 2002, 35, 90-94. [CrossRef]

64. Stulić, V.; Vukušić, T.; Jambrak, A.R.; Bačun-Družina, V.; Popović, D.; Mrvčić, J.; Herceg, Z. Quantitative microbial assessment for Escherichia coli after treatment by high voltage gas phase plasma. Innov. Food Sci. Emerg. Technol. 2019, 53, 26-35. [CrossRef]

65. Moisan, M.; Barbeau, J.; Moreau, S.; Pelletier, J.; Tabrizian, M.; Yahia, L. Low temperature sterilization using gas plasmas: A review of the experiments and an analysis of the inactivation mechanisms. Int. J. Pharm. 2001, 226, 1-21. [CrossRef]

66. Chen, C.W.; Lee, H.-M.; Chang, M.B. Inactivation of Aquatic Microorganisms by Low-Frequency AC Discharges. IEEE Trans. Plasma Sci. 2008, 36, 215-219. [CrossRef]

67. Nguyen, D.V.; Ho, P.Q.; Pham, T.V.; Nguyen, T.V.; Kim, L. Treatment of surface water using cold plasma for domestic water supply. Environ. Eng. Res. 2019, 24, 412-417. [CrossRef]

68. Barišić, V.; Flanjak, I.; Tot, A.; Budeč, M.; Benšić, M.; Jozinović, A.; Babić, J.; Šubarić, D.; Miličević, B.; Ačkar, Đ. 5-Hydroxymethylfurfural and Acrylamide Content of Cocoa Shell Treated with High Voltage Electrical Discharge. Food Cont. 2020, 110, 107043. [CrossRef]

69. Tessier, D.; Oguic, C.; Pinart, J.; Aaron, J.J. Usefulness of a Technique Based on Negative Corona Discharge for the Degradation of Selected, Condensed PAHs: Application to the Oxidation of Anthracene and Similar Structures. Turk. J. Chem. 2001, 25, 157-164.

70. Wang, C.Y.; Hsu, C.C. Characterization of plasma in aqueous solution using bipolar pusled power: Tailoring plasma and optical emission with implication for detecting lead. Plasma Process Polym. 2019, e1900159. [CrossRef] 
71. Ceccato, P. Filamentary Plasma Discharge inside Water: Initiation and Propagation of a Plasma in a Dense Medium. Ph.D. Thesis, École Polytechnique, Palaiseau, France, 2009.

72. Grymonpré, D.R.; Finney, W.C.; Locke, B.R. Aqueous-phase pulsed streamer corona reactor using suspended activated carbon particles for phenol oxidation: Model-data comparison. Chem. Eng. Sci. 1999, 54, 3095-3105. [CrossRef]

73. Sun, B.; Sato, M.; Clements, J.S. Use of a pulsed high-voltage discharge for removal of organic compounds in aqueous solution. J. Phys. D Appl. Phys. 1999, 32, 1908-1915. [CrossRef]

74. Du, C.M.; Yan, J.H.; Li, X.D.; Cheron, B.G.; You, X.F.; Chi, Y.; Ni, M.J.; Cen, K.F. Simultaneous Removal of Polycyclic Aromatic Hydrocarbons and Soot Particles from flue Gas by Gliding arc Discharge Treatment. Plasma Chem. Plasma Process. 2006, 26, 517-525. [CrossRef]

75. Ouf, S.A.; Basher, A.H.; Mohamed, A.A.H. Inhibitory Effect of Double Atmospheric Pressure Argon Cold Plasma on Spores and Mycotoxin Production of Aspergillus Niger Contaminating Date Palm Fruits. J. Sci. Food Agric. 2015, 95, 3204-3210. [CrossRef]

76. Park, B.J.; Takatori, K.; Sugita-Konishi, Y.; Kim, I.H.; Lee, M.H.; Han, D.W.; Chung, K.H.; Hyun, S.O.; Park, J.C. Degradation of Mycotoxins Using Microwave-Induced Argon Plasma at Atmospheric Pressure. Surf. Coat. Technol. 2007, 201, 5733-5737. [CrossRef]

77. Bosch, L.; Pfohl, K.; Avramidis, G.; Wieneke, S.; Viöl, W.; Karlovsky, P.; Ten Bosch, L.; Pfohl, K.; Avramidis, G.; Wieneke, S. Plasma-Based Degradation of Mycotoxins Produced by Fusarium, Aspergillus and Alternaria Species. Toxins 2017, 9, 97. [CrossRef]

78. Dasan, B.G.; Mutlu, M.; Boyaci, I.H. Decontamination of Aspergillus Flavus and Aspergillus Parasiticus Spores on Hazelnuts via Atmospheric Pressure Fluidized Bed Plasma Reactor. Int. J. Food Microbiol. 2016, 216, 50-59. [CrossRef]

79. Grinevich, V.I.; Kvitkova, E.Y.; Plastinina, N.A.; Rybkin, V.V. Application of Dielectric Barrier Discharge for Waste Water Purification. Plasma Chem. Plasma Process. 2011, 201131, 573-583. [CrossRef]

80. Rincón, G.J.; La Motta, E.J. Simultaneous removal of oil and grease, and heavy metals from artificial bilge water using electro-coagulation/flotation. J. Environ. Manag. 2014, 144, 42-50. [CrossRef] [PubMed]

81. Jokić, S.; Pavlović, N.; Jozinović, A.; Ačkar, Đ.; Babić, J.; Šubarić, D. High-Voltage Electric Discharge Extraction of Bioactive Compounds from the Cocoa Bean Shell. Chem. Biochem. Eng. Q. 2019, 33, 271-280. [CrossRef]

82. Li, Z.; Liu, L.; Fan, Y.; Xi, J. Kinetic modeling for high voltage electrical discharge extraction based on discharge energy input. Food Chem. 2020, 314, 126168. [CrossRef]

83. Almohammed, F.; Koubaa, M.; Khelfa, A.; Nakaya, M.; Mhemdi, H.; Vorobiev, E. Pectin recovery from sugar beet pulp enhanced by high-voltage electrical discharges. Food Bioprod. Process. 2017, 103, 95-103. [CrossRef]

84. Žuntar, I.; Putnik, P.; Bursać Kovačević, D.; Nutrizio, M.; Šupljika, F.; Poljanec, A.; Dubrović, I.; Barba, J.F.; Režek Jambrak, A. Phenolic and Antioxidant Analysis of Olive Leaves Extracts (Olea europaea L.) Obained by High Voltage Electrical Discharges (HVED). Foods 2019, 8, 248. [CrossRef]

85. Boussetta, N.; Vorobiev, E.; Le, L.H.; Cordin-Falcimaigne, A.; Lanoisellé, J.L. Application of electrical treatments in alcoholic solvent for polyphenols extraction from grape seeds. LWT 2012, 46, 127-134. [CrossRef]

86. Barba, F.J.; Brianceau, S.; Turk, M.; Boussetta, N.; Vorobiev, E. Effect of Alternative Physical Treatments (Ultrasounds, Pulsed Electric Fields, and High-Voltage Electrical Discharges) on Selective Recovery of Bio-compounds from Fermented Grape Pomace. Food Bioproc. Tech. 2015, 8, 1139-1148. [CrossRef]

(C) 2020 by the authors. Licensee MDPI, Basel, Switzerland. This article is an open access article distributed under the terms and conditions of the Creative Commons Attribution (CC BY) license (http://creativecommons.org/licenses/by/4.0/). 